\title{
パルテノンには空があつたか
}

\author{
正員㴰 澤 県 马 $^{1)}$
}

\section{两客梗 概}

(序諭) パルテノンK果して探光の空があつたか否かといふ問題は既に僻決された如くで、其筫未だ僻決され

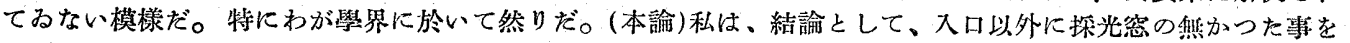
主張するが、其理由は大姴次の如くだ。即ち、パルテノンは國家の川央金庫であつた事、內に安置された女新 像は日光中風雨に當てられない性質のるのであつた事、入口以外に窓のない方が神話の精神にも適ひ、文美的

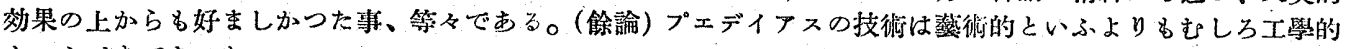
といふごきであつた。

\begin{tabular}{|c|c|c|}
\hline & 目 & 次 \\
\hline I & 序諭 & 三問題中の一つ \\
\hline & 本論 & 復興事業 \\
\hline & & 黃金・象牙の像 \\
\hline & & 女神の盖生法 \\
\hline & & 中央金厚 \\
\hline & & パルテノン銀行 \\
\hline & & 東位の制 \\
\hline & & へラスの太陽 \\
\hline & 全铨 & 黃金の行方 \\
\hline
\end{tabular}

\section{I 序一論}

\section{三問題中の一つ}

世界史上最美の建築と言はれるパルテノンに關して は、既にあらゆる䂙究がー應は䳔急されたかと思らっが、 問題は眽に悉く解決したといふわけではない。パルテノ ン确究の初期時代以來の問題であつて、しかも今日な活 未解決のま惩案として留保さ机てるる(と私の信ずる) 間題表、私は今三つ擧げる事が出来る。第一はその構圖 形式、即ち所謂「比例」の問題。第二はその微妙なる曲

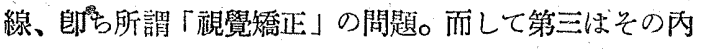
部の探光、即ち所謂「天空」乃至「光階」の閒題、であ る。そのうち、第一と第二の問題に就いては、私は既に その一部を別の機會に㤻いて發表してるるから此所には 差控える。茲に、私は更めて籍三の探光問題を提起し、 大方の高㸚を仰がんとする次符である。

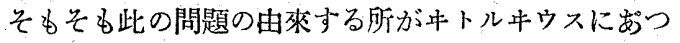
たといふ倳は一つの運命であつた。たしかに此の閣題に 關する彼の敍述は懓眛である。そして前世紀以來幾多の 學者たちは次々に、そのあらゆる可能性について論議し たのである。幾種類かの復原圖が提案された。が、やが て時と共に、學界の一般的傾向は或る一つの落着黠に向
つて漸次鎮清してて行つたかと思はれる。少くとも吾々は 斯道の碩學ミヘエリスの次のやうな赫告に一應の敬意を 表さねばならないであらう。

即ち彼俚此の問題に就きバッサイのアポロ神既— その設計者はパルテノンの設計者なるイクチノスであ つた一に關說して述ぶたのであるが、日く、「此の神 闹の探光問題、屯た所謂青天非殿堂 (Hypaethral Tempel）の性質に就いては、當時學界の疑問のーで あつて、數十年間杽決する所がなかつた。あらゆる可 能的或は不可能的の技術的解釋が提供せられ、“熱心に 議論せられたが、遂にドョルプエルト (Dörpfeld)の 周到な研究の賜として(1891)、今やギリシャ新间に於 いてはきらきらした外光を上方から空內に取るととが 典かつたと云ふ磪信がー般に行はれることになつた」 そ。(A. Michaelis：㴼田兆作氏臎「美術考古學登見史」 p. 63.)

現筫的事情は、しかしながら、必ずしも此の碩學の觀 取した通りでないらしい。何となればその後に發表され た幾多の歐米の建築書には依然として背天井や屋根空を もつたギリシャの神殷 の圖が探用ざれてるるからであ る。近年に於いてさいも、極めて手の込んだ光階の方式 が新案として提出された程忙 (Journal of R. I. B.A.

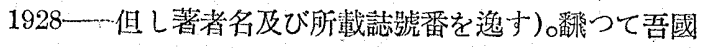
の學界について見るに、たとへば吾人の最も信賴をかく べきわが建築學會の發行にからる「酉洋建築史參考圖焦」 (但し昭和 6 年版) の如きは極めて等敢なる天空說を支 持するもの〉如くである。しかも其所なる女神つテナの 像は、その首は軒蛇腹よりも高く、そ穴長槍の鋒先は屋 根面を拔け出てるる程である。當惑せざるを得ないのは 果して私一人であららか。或は「しかしながら希腦神琪

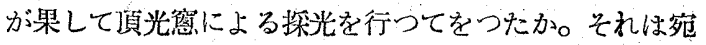
わパルテノン神眀の美とひとしくーつの謎でむる」(岸田 日出刀氏 :「䧒列室と光線」新興繁術、昭和 5 年 1 月號)

1) 神戸高等工業學校教授 
そいふ言㷊せたりが最も自重した結論でもせららかと思

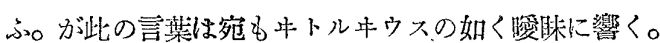
何となれば間題の對象としてはあまりに漠然たる「希臘 种殷」であるし、論理的關聯としてはパルテノンの間題 として、その「美」との徉比に於いて、考へられてるる かの如くだからである。

事情は大凡斯くの如くである。これ今私が敢て茲に、 此の古めかしい問題をるら一度取り上げて見ようとする 所以である。

\section{II 本，論}

\section{復興事業}

時は紀元前 480 年の夏であつた。テルモピレの險を哭 破したペルシャの大軍はアッチカ州に殺倒した。坭勢慨 に非なりと見たアテナイでは、まづ婦人と小兒とをぺ ロポネソス地方やサラミス、エギナの島々に避難せし め、武裝能力峁る男子は悉く船に乘じて一旦サラミスの 灣に退きつ〉最後の沠戰を䇾はねねばならなかつた。かく てアテナイの市街とアクロポリスの聖域とは染なる敵軍 の侵す所となり、民家と神殿とは悉く荒掠しつくされ た。當時アクロポリスには舊パルテノン（郎ち第二期神 殷）が起工されて間もない䪸であり、架設工事用の木材 に被はれてるたが、敵軍は忽ち之に火を放つた。アテナ イの市民たちは流離の空から、自分たちの故鄉が真狄の 炬火に一朝にして焦土と化する有樣をば、たら゙傍觀する より外はなかつたのである。

さて、今更らしくも斯樣な話、成に世間周知の事に屬 する。が、此のアテナイの未曾有の慘事こそは、やがて 䗆かしくも生れ來つた所の新しきパルテノンのために重 要な前奏曲となつたものである。吾々は更めて此の歷史 談を茲に想起せねね゙ならぬ2。何となれば、本篇の主題た るパルテノンの「探光」閣題のためには、特に此の前奏 曲は䨘要な主導旋律を響かせるものだからである。

却說。同じ年の秋、将ラス灣の決戰でアテナイは逐 に勝つた。單に敵軍を繁隇したの久ではない。實に世界 戰史に於いても稀に見るところの赫《光る勝利により

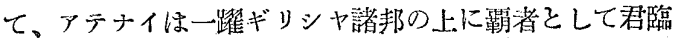
する事となつたのである。こにアデイを盟主とする デロス同盟が成立する。然かも此の戰勝と䩴業との由つ て來る所は一に守䜅神アデナの加護にあつたと信ぜられ

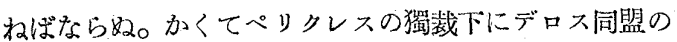
金庫がデロス島の神殿からアテナイのアクロポリスに梨 される事となる。デロス同盟とは名のみにして、蕒はアテ ナイ帝國が完成する。女神アテナは今や同盟の守護神で むり、同盟の凟金は其の一部を割いて女神のために神殿 を造營すべく留保される事となる。泫に、ペルシャ戰役 以來アテナイ人の宿願たりし神殿の復興計畫が。始めて
豐かなる財力の下に實現する事となるのでする。

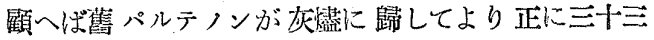
年、アテナイの人及は往年の鹪ましい經驗を、よもや忘 れてはるない䈏である。

\section{器金・象牙の像}

パルテノンは守護神アテナの殿堂である。アテナに献 げられ殿堂である。ペリクレスはアテナイ人を代表し

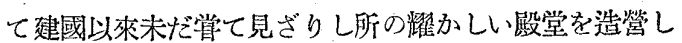
て神に献げたのである。然らだ。パルテノンは如何に美 しい建造物でせつたにしても、气れは要するに鬳物であ る。たよ゙、それが女神の化粧亚に入れるには大きすぎる 䰜物だつたといふにすぎない。杂自身が言はが化粧厘 であつた。否、化粧を施された匣であつた。そして、吾 人は如何に考へるも此の化粧された匞がその中に安置さ れを女神の像よりる貴重であつたとは信ずる事が出來な い一極めて現䆩的な意味に於いて。

女神の像はいはゆる「畟金・象牙の像」(Chryselephantine Statue)であつた。神殿建立の經費は固より多 大な多のであつたが。此の神像のためには一厤多大なる 經費か㴗求された。金額の記載忹不去にして不完全で正 確なる總額を算出する事は不可能である。僅かに推定す 札ばバルテノンの經費は凡そ700 タラントを數いる…… ピロコロス (Philochoros) の登言によれば、像に使用 された黄金の全量は 44 タラント〔因に、ツキデデスで は、恐らく概算にて、40タラントさえれにアフリカにて 巨費を投じて得を象牙の價格及び工僓を加へれば財寶官 の支泏額は 700 1000 タラントに澾するでむらう」(M. Collignon 著、富永䊍一氏譯「パルテノン」p.57Kよる)。

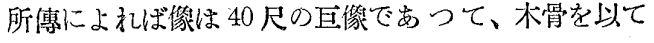
組立て、黄金と象牙との延板を以てその外泟を整へてる たのである（嚴密には、㭘は恐らく扇柏材であり、黄 金と受牙との他に種及なる璸石類、青銅類、大理石、黑 檀等が用ひられてるた)。神像の下には別に一靑銅板が設 備され、之に所等の貴重材料の数量が、銘記せしぬられ た。當時の歷史家ッキデブスの證言によれば。賽に斯く の如きこそ金塊眝藏の一手段でもつて、一朝有事の秋に はその像の黄金部分は總て之を取外し得る仕掛けになつ てなた(後說「中央金庫」の項參照)。而して一一傳記家 プルタルコスの語る所によれば一一の仕掛けは豫め周 到なるぺリクレスの配虑として用意されたものであつ て、現にその制作者プエデイアス自身が黄金萪盓罪とし て栖告された時、プエディアスは告發者をしてその神像 より總ての鱼金を取り外して科量地しめ。以て自身の溸 白を證明したとのことである。

吾々は、この不出世の大天卢プエデイアスの作品— 敢て言ふ。ギリジ藝街の最高峰的作品一正浃して「青 白い大理石」ではなかつたことをまづ考へねばなら欢。 
それどころか、その神像は留なる禮拜の對皇たるに止ま

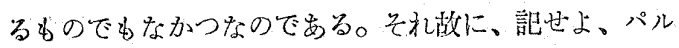
テノンは洪して單なる馓覽會場でなかつたといふ凄を。

\section{女神の養生法}

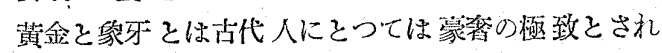
た。その意咮に於いて此等のものは古代人に留求され愛 好された。ま像可の彫像に黄金の東裳を请好ること は、小さい洆品ながらも、既に古くクレタ島に於いて 行はれてみを航だ。が、斯くの如き貴重品を以つて高さ 40 尺にも及ぶ区像を制作するといふ倳は、蕒にプエデ イアスの如き天才の出現を街たねばならなかつたのであ る。プエデイアスがギリシャ彫刻界に於ける最大の天才 であつたそいら定評の由つて來る所は、實に斯かる意味 での彼の獨創性にあつたので后ないか、そ私は考へる。

黄金・象牙の像方非凡なる熱術的才能を必要とした事 は言ふまでるない。が、更に之れを工學的拔術として見 るも、その巨大な术婴の組立てには建筑的・力學的技術

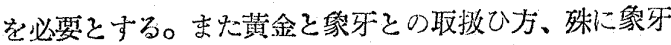
の處理方法には一一固より其所には古い時代よりの傅承 も岁つたでも安ららが一極めて特䅀な技能を必要とし た。

プエディソスの黄金・象牙像に關して該博な研究を骂 䒧したのは十九提紀に於けるフランスの篤學者ド・アン シ (Quatremère de Quincy) である。彼はその著「オリ ムピアのジユピターーゼウス]」に於いて、古代の大旅行 家パウリニアスの記錄に基づいて次の如く推定した。郎 ち「古代人は牙の中部から圆筒狀のるのを切拔いたもの

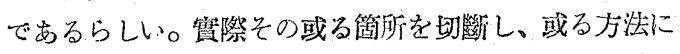
よつて柔顿にし、然る後に之れを押擴げると、その圓周 に相當する幅の平板が出來るわけだ」と。而して現代の 象牙細工の專門家の語る所によれば、斯くして得られた 牙材は䤏や巴且杏油に浸寸と柔軟化し、更に㱦性アルカ リにて處理するならば硬化して丽び舊態に復ずることが ない、との武である。但し、古代人が鿓際に於いて、此 の言はぶ製板工業を、果して如何なる風に行つてるたか

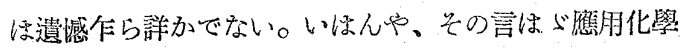
的操作の過程に於ける蒗形美量の作業に至つては全く不 明でまる。恐らくそれは古代に於いても、秘技䇭の秘技 に屬してみたであらら。まを其所には當然プエデイアス の獨創的發明必䂆想されねばなるまいかと思ら。

さて、そにかく斯かる秘挍によつて美事な神像が出來 上つたとする。が、その後の像に碰する害は心養生法は

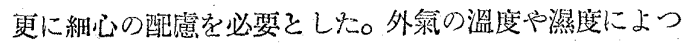

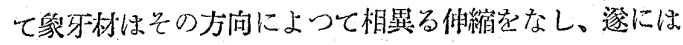
娄及思ひダけぬ歪曲をさへ结ずるに至るのである（現代 人は此の事を往及にして撞球用の球にて經驗するであら う)。そして古代の大天才の傑作とてる時には斯かる宿命
から免れる事は出來なかつたのである。 パウサニアスの見聞した所によ机ば、オリムピアの ゼウスの新像一一青ふまでをなく、之はプエデイナス の第一の桀作と言はれたるの一杜58 尺の翼金・象劣 像であつたが、その座の前には垚い板石が䑤かれて、 其机に大理石の緣を周らし、其所にはォリ占油が用意 されてあつたとの事である。神殿に近き梁地より來る 缹埭の影響加ら像牙材を保護するためには、常に油に

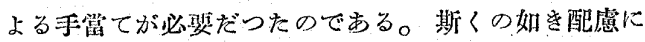
も拘らず、後牛此の神像の像牙板は䍝れ出した。そし

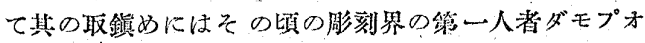
ンの手を煩はさ叔ばならなかつたと售一られる。

アテナイに於ける事情标オリムピアの㭲間とは反對

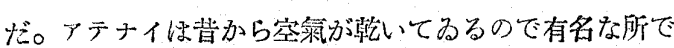

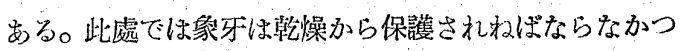
た。從つてパルテノンの內陣には恐らく何等かの方沠で 常に水が用意されてるな、と洘へざるを得ないだらう。 パウサニアスによ狆ば、エピダウロスのアスクレピオス 神殷にも亦黄金・参牙の像があつて、其所でもやはり乾 燥が防がれねばならなかつたが、其所では吅妙にも神像

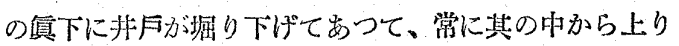
來るところの水蒸氯沐浰用されてるをとの事である。だ 林アテナイのアク口ポリスに於いて斯かる扑水を求める 事は絕望であらう。吾及はパルテノンの內漣に水乃至油 のための何等かの施設を要請せねばなるまい。として倫 传女神の像の弓ちには、水か油堂補給する何等かの仕掛 けが、プエディフ大獨特の秘密で考案されてるたとさへ も考へねばなるまい。

ローマの大博物學者プリニウスの著述の中には「アル テミスの神像には多くの孔分紫たれ、それに油を注入し

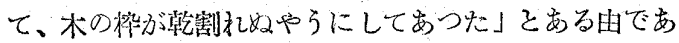

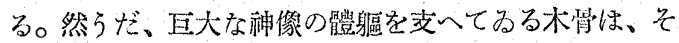
礼自身が既に一つの嚴然たる木造建築だ。此の大架構の

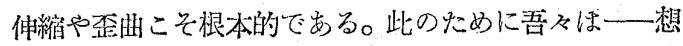
像の及ぶ限りの可能性の下に一一果して如何なる配虑を 以て履むべきであららか。

わが㜤は、大树ながら、斯くも生來蔳柳の質であつ た。露をも光をも椆はねばならぬ身であつた。彼女に永 遠の青春を保證してやらねばならぬ國手の責任は、何と しても彼女の身を、まのーシスの太陽の光と熱と、更に

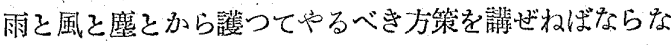

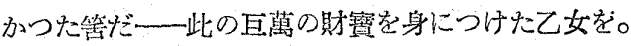

(本項恔特に、砂本悅次郎氏著像」に負ふ所大である。 私は然に此の篤學なる大藷述に敬意を琵する。）

\section{中 央金庫}

デロス同盟の金簐がアクロポリスに移されなことは既

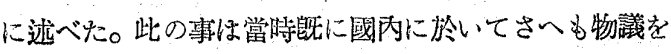


かもした程げが、結局ペリクレスの獨裁下に於いて、ア クロポリスはアテナイ帝國の金融城塞と化した。它の剘 務むやがては女神アテナの財寶官が掌握する事となうた のである。かくて、パルテノンこそは大理石を以て筑か れ九所の中央金庫に他ならなからたのでもる。實にあの 巨大な黄金・象牙像は一一諸他の黄金神體や珼物をる含 めて一一如何に神の名に於いて成就したとは言へ、現實 には既に述べた如く、金塊眝藏の一手段であつた。かく て、極言すれば、パルテノンとは斯かる現實をカムフラ ージュせんための「化粧㢆」だつたのである。さればべ リクレスとプエデイアスとが共謀して神への不敬罪を犯 したと告發した反對黨員にも若下の分を認めてやらねば なるまい。

翻つてまを兹に想起せよ、三十餘年の昔を、せの時ア クロポリスはペルシャ軍のために荒掠されパルテノンは 灰㘕と化したではないか。詩人アイスキロス一彼はか つてヌラトンの野に、ついでサラミスの海に舊戰した勇 士であつたが——岕の當時の事を、ダリオス王の口を偕 りて、次のやらに語り聞かせてるるではないか。

「奴等はギリシャの地に侵入して、神修を毁ち神貶を

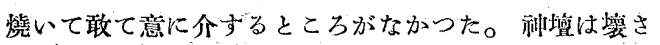

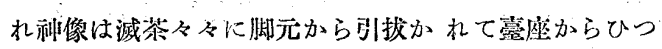
くり返された」そ。(アイスキロスの践曲「ペルシャ人」 の一節)

實に坐くしい記憶ではないか。尤むべルシャは既に眼 界から消文去つたが、今や眼前には强敵スパルタがるる。 國家の伦機は何時到來せ好とも限らない狀態である。乞 して萬一の場合にも立至らば、女神とても忽ち能骨だら けの夜汉と化して國家を救はねね゙ならぬか子知れ如。若 しも假りにもの三十餘年前の時の如き事態を再び繰返 すことにでもなるならば、人及は女神の像を手速く解體 し、その財寶を携帶してピレッスの港へと急が稀ばなら

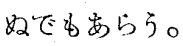

ッキヂデスの證旁は何よりも信頪され朴ばなるま い。日く「若しも一朝彼等吕䋓對絕命といふ所まで逐 ひつめられたとしたら、彼等はアテナの黄金の飾りさ へも㔀取つたでもあらら。何となればその像は 40 タす ントの純金を身に新けて居り、しかると机は全部取り 外すととが出來当やらになつてるたからである」(ツキ デデス「ペロポネッス戰役」II，13. 但し、R. Crawley. の英謵によ方)

吾々は更めて、茲にペリクレスの梁虑とプエデイッス の秘技とが那邊にまで伎儿でるなかを顧みねばならな io

事實は最も有力な證言者である。パルテノンが竣工す ると共に、やがてぺロポネソス戰役が勃發した。すると、 アクロポリスの山上からは、幾體かの黄金像は何時の間 にか神隱れし給らて、貨撆鑄造工場の爐へと天下つたの
である。

かくてこっに一つの動議が許されるかと思ふ。郎ち若 しも現代に於いて、パルテノンと類比的な機能」をもつ 所のるのを求める者あらば、何所よりもまづ國立銀行の 地下室へ行け、と。實に其所なる大金庫公こそは最も進 化せる現代のパルテノンだからである。

吾ふは中央金庫パルテノンに於いて、少活依然として 明るい䓡の證跡を摸索しつડけねばならぬのであらう か。

\section{バルテノン銀行}

竣工後のパルテノンは單に國筧としての金塊を睦藏す

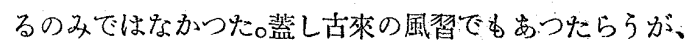
此神殿はまた不安なる市民のために最る安全なる保謢函 を提供したのである。

パルテノンの財錴管理に關する研究書としては炊の 如きものがある。本諭の主題に對しては稍間接的な資 糊であるが、極めて學笔的で許細な著述である。念の ために玆に紹介する一W. S. Ferguson: “The Treasurers of Athena," Harvard Univ. Press, 1932.

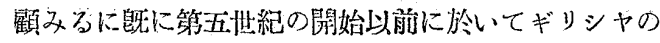
諸市邦は、實物經激より貨盤經濟への推移を見た。當時 の哲學者へラクレイトスはその有名な火の原素說に於い て「をたか子阅品が金と交換せられ、また金が商品と交 換せらるつ如く、萬物は火に變じ、火は萬物に變ず」と 注韭した程である「高橋誠一郎氏:「經濟學前史」p.109〜 120 參照）。勞働者としての奴隷も金錢を以て購はれ、か くて存力なる富者は原始的乍ら屯工場經營をな机至 り、茲に資本の價值か重要視されるに至つた。いはんや

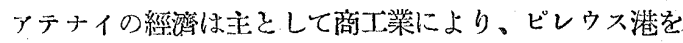
介して國際的市境をさい獲得したのである。かくて既に 五・四世紀の交に於いては民間には金融業者たる一種の 銀行家され子出現した。が、如何なる銀行とい的どもわ が「パルテノン銀行」の堂々たる橉いに及ぶちのはなか

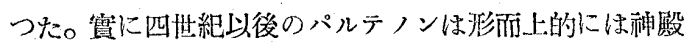
であつたららが、形而下的には明らかに國立銀行で出つ た。而して、その言はら゙バンキング・ボールは堅牢な格 子を以て睹まれた西侧の立關（オピストドモス）であつ た。此所ならば確加に今日の大銀行の營業室に山劣らぬ 明るさであつたであらら。そして此の事は、その奧の窒 （本來の「パルテノン」室）が暗い寶庫であつた事空推 定せしめる。且つまた。此の西側の事情は、やがて東側 なる表玄關と內陣との關係に對しても類推されるであら ろ。表玄關もまた獨立した一つの窒として「プロナオス」 そ呼ばれ、其所の有樣は咅文關と略同樣であつたと推定 される。從つて此所でるまを、內陣に於いて取敃ふれは 不適當な事務的處理が行はれたですらら一恐らく內陣 は薄曋かつたであららから。 
神像が神隱れして鑄造工場へ天下るためには、神殿の 內陳は晤かつたと考へる方が、少くとも常識上、好都合 である。だがまた、䕎いといふことは恐らくあらゆる罪 禍の基であらら。既に神及は死んだ。パルテノン銀行に 群臨したものは浮世の俗人共であつた。アテナイ市の鳥 政者たちは、ぺロポネッス戰役の未期（407〜6B.C.)に 至つて軍資調達の急に迫られて、パルテノンから天下つ

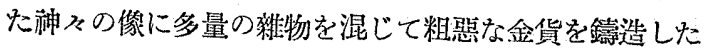
のである。茲に於いて吾々は、次のやうなプラトンの對 話篇の一節を意味深く讀まねばならぬ…...

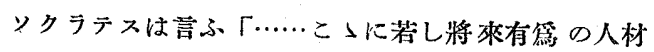
を得るならば、よろしく之をアクロポリスに保護して 俗世の害毒よりま好かれしめ。。金塊などょりる、む しろ此の種の人物の上に極印を施し、以て俗人共の手 管〔による品質の惡化]を豫防せ补ばなるまい.......」 と。(Platon : Menon, 89)

ギリシャる亦、要するに人間の世の中であつた。ギリ シャも亦俗世であつた。むしろ、ギリシャこそ俗世であ つた。占今無双の美建築パルテノンとても此の俗世の混 沌から脫机る事は出來なかつた一私の心まで曋くな る。

\section{東 位 の 制}

暗くなつたのは私の心だ。斯んな自分勝手な氣まぐれし は、歷史砽究にとつて、特よそ意味ないことで岁る。だ

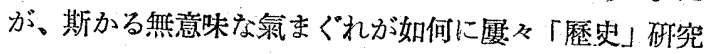
の名の下に默許されて來たことであららか。かくて、吾

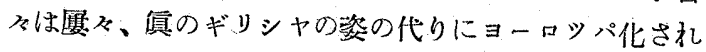
たギリシャを見せられた。アポロンの姿は何時の間にか フアウスト化されてるたのである。

\section{フアウスト(盲して)}

……しかし心の中には明るい光が輝く、

打前たち! …........

扎れが大膽に目論んだ事を、5まく見せてくれ（ゲ ーテ：「フアウスト」)

更めて問ふ、そもそもパルテノンの探光問題は何に由 つて生じ來つたか。蓋し、直接の機線となつたるのは年 トルキウスの「建築論」の天空說であらら。此の書がク ラシック建筑に關する唯一現存の古典である限り、此の 書に㕠據衣求めるのは固より當然の事である。加之彼の 交面からすれば、天空存在の娥疑は一應はパルテノンの 上にかけらるべきでもあらら。が、パルテノンが指され てるるといふ明證は實は何所にも見出されないのでも る。一尤も以前と今日とでは中トル块ウスに眰する世 人の評價は大いに異る所があるがー一それよりむ、探光 閣題のもつそ根源的な岶來は、實に近代のバルバロスの 「度目」とその「大脆な目論多」とにあつたのである。 今更の如くパルテノンの廢墟の筑を仰いで天空を䍗し出
さうとしたのは北方人の「心であつた。寒く且つ晤い北

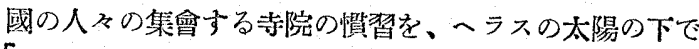
「大㬿に目諭儿だ」のである。パルテノンは言ふまでもな く、會堂ではない。气れは神聖なる處女が、彼女の愛鳥「ふ くろふ」一此の暗夜の鳥一と共に䈮る隱處である。 そしてその入口の屝の前には、彼女の黃金のきらめきを 氯にし作ら、財䈏官が嚴重に張番をしてるるのである。 だが、如何に女神の像が金塊詝藏の一手段であつたに しても、そ札ぺリクレスの深慮のこそであつて、表向 きのことでなかつたのは勿論だ。大藝術家プエディアス が、その制作に當つて、その作品が、ペリクレスの梁慮 を滿足させつ〉。同時に參詣する人从の眼にも及ぶ限り 美しく映ずる事を念愿し、且つ成功した事は想像に難く ない。それ故にこそ耀かしい評制をかち得たのである。 しかも更に、此の女神の管が皮ぶ限り美しく見えんがた めに、その全建築工事が指圖されたで市ら弓事す、ま た想像に難くない。何となれば、プェデイアスはパルテ ノンの工事總長であつた。

法に一度だけ、私の勝手な「心」もちを許してもらひ 度い。さて、若しタパルテノンに天然百至光階があつた そするならば、其れから射し入るところの强烈な、そし て交錯する不統一な光線が、果して神像を美しく畫き出 寸事に成功したであらうか。却つて、唯一のE大な傎正 面の入口方至欄間から一氣に射し入る光の力が、黄金・ 象牙の像を暗い室の中に耀しく憲き出寸事が出來たので はなかららか。私は、祭日一それは數日つぶいを— の早朝に、あの巨大な入口を通して、女神の寶冠から、 顏から、鍴から耀いて來る朝日のきらめきを仰ぎ見て鹳 喜したギリシャ人の心もちを想像する。此の事を「想像」 せずしては、ギリシャの諸秆殿が何故にすべて一但し 恐らく夫々個有の日取に應じて一東位の制の゙原則を遵 本してるるかを私は首肯する事が出來ない。著明な例外 そ考へられるバッサイのアポ口の神殿る、その外形は北 面であつたが、內陣の奧の神像は東面して、その直前心 は特別の入口が明けられてるた。しかも之がパルテノン そ同一のイクチノスの設計であつを事は特に注意を要す るであらら。

ザが斯くの如きも。所詮は私の勝手な「想像」でむら らか。諸他の神殿の事は整く措く。私は今省汪幸にして 殆儿ど完全に復皂し得るパルテノンの東側の破風に示さ れた神話の光景を顧文る。それは一既にパウサニアス が書き遺した如く一女神アテナの誕生の場面である。

それは「アテナに等するホメロ六風の詠歌」の詩人が美 しき詩交にて語つて方る警くびき奇蹟である。美しく

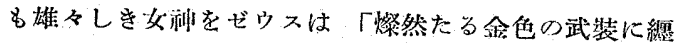
はせて」彼の大きな頭から生み落した。折しる太陽( リオス）は馬圭御し、車は海の上に浮び上る所だ。ひ きかへて、月（七レ一未）の車は海の彼方に沈多行か 
らとする。(Collignon，管永瀷、op. cit.)

プエデイアスは紳ふの像を作るに當つて常にホメロス を心に誦してみたといる。かくて彼はあの東側の破風の

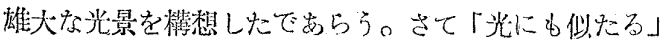
女神の姿を神話の如く現前せしめるものは、あの神殿正 面の大きな入口前ら射し入る朝日が「金色の武装」を辉 した時を除いて外にはなかつたであらう。

\section{ヘラスの太陽}

朝日の光はさること乍ら、盾畫の太陽の熱は恐らく䔬 金・象牙像のなめには馓はるべきものであつたらう。閶 ネとしてアクロポりスを照らすへラスの太陽一こっで 閥題がまた二つ出て來る。

第一は神殿內部の通風の問題だ。此の大理石の金庫が 熱せられた時、室内の空氣の交替が不完全であつたなら ば、E大な神像は當然好ましから影響をらけざるを得 まい。(現代の銀行建筑に於いても金庫內の通風裝置は最 も因難な問題に屬する）若しる其の室內に急激な录流を 生ぜざる程度に於いて絕えず換氣が行はれたななば理想 的であつたらう一そこで天管や光階がまた欲しくなつ て來さらだ。が日光の直射は依然として㕆はれねねばなら $\$ 20$

第二には、然らば天空や光階を塞いだとして見る。所 がどうだ、明るいーラスの太陽は、屋根と格天扑とのう すい大理石板を透して、室內に極めて微妙尔間接照明を もならす見込文でむる。パルテノンは周知の如くペンテ リコンの大理石を以て築か机たもの愔が、明らかにその 屋根のタイルと、而して恐らくその格天其のスラブとは 女の白く牛透明なパロスの大理石で張ら忆でたのであ る。現代建築に於ける如何なる雪燈照明法为斯儿な大規 楬な施設を得る事は困難だ。そして此の微妙な溥明のた めには天䓡や光階は却つて邪麼である。

さて、斯ういふ一㖶の矛盾に對して解決の鍵を與へる ものは、あのオリムピアやバッサイで拾はれてといふれ の明いた大理石の屋根タイルでをらら。固よりそれはな ら゙所タにしか用ひられなかつたるのであつて、孔の閏に は水返しの緣がついて居た。だから雨量の少い地方では その孔から跳边を雨水の如きは殆んど閏題とはならなか つたであ55。却つて大抵の日にはその孔加射し大る

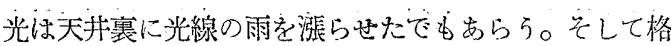
天井の組合せ力は、此の三つの侵入者を防きつ小、通風 のために適宜の空腺を殘す事が出來たにらがひない。 にかく、斯堛にして、通風々称光との問題し最初に心配 した程のことはなさらうである。

假りに、此際通風には成功してる、空內は依然として 暗からたとする。然らば見よ、正面中央の大いなる大口 を。入口の上部の大いなる欄閒を。明るいへラスの太陧 に對しては、これだけにて、既に十分に、此の神殿とし
ての探光の目的を達した筈である。

$$
x \times x \times
$$

更めて開ふ、パルテノンには空があつをか、と。若し

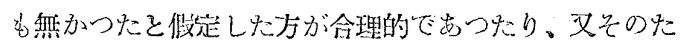

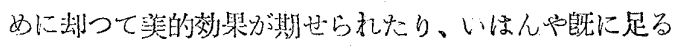
だけの明りが得られてみたといふ福なことにもなるなら

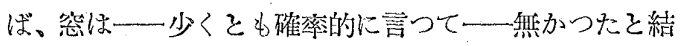
論せざるを得ないであらう。

\section{III 餘論}

\section{㙼金の衍方}

パルテノンと黄金・象牙の像とが完成して所謂ギリシ

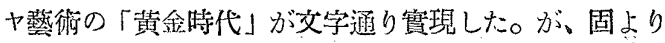
パルテノンは美術館ではなく、黄金・象牙の像は陳列品 ではながら。しかるに後世の人々は、パルテノンが美

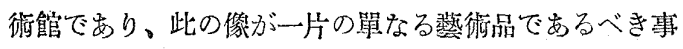
を姴請したかの如くである。その所謂「蒜術」とは何で

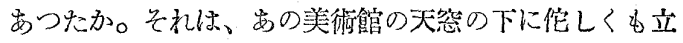
てる寻ざめた大理石の姿ではないがとて、斯かる㙯

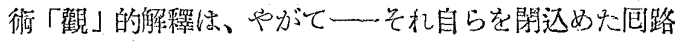
をたどつて一遂にパルテノンの屋根の上に、非程術的 にも!然ざまな大峔をあけてしまつたのである。

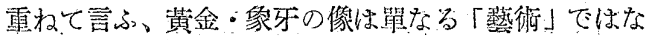
かつた。その存在理由に於いても、その成立過程に於い

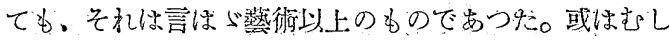

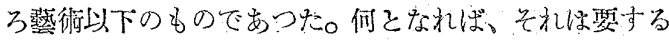
に見窟汸會の一機關にすぎぬ子のであつたから。だが、 その存在性は國家に於ける最高の政治的理由上に立つ てるを。而してその成立過程を單なる浩像術として見る

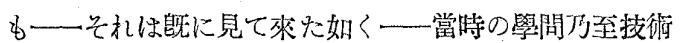
の可能性の最高限度を極めたるのと洘へざるを得ない。 然加を并れが「藝術」として千古の傑作であり得た所以

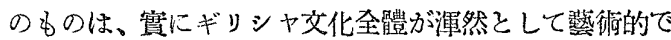

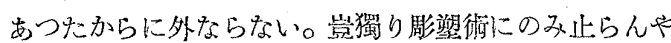
である。だから、プエデイアスが大藝峝家であつたとい ら事は、勝義のギリシヤ的意味に於いて、彼が偉大なる

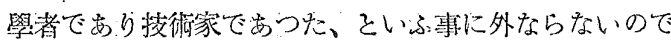
ある。

正義の詩人へシオドスは人間社會の陸落を嘆じつ〉。 過ぎし時代を「黄金の時代」として追懹した。「こがね色 なす」といふ䜾はホメ口スが特に好儿で歌つて以來、常に ギリシャ人の愛用したところでする。かくて神及の像が

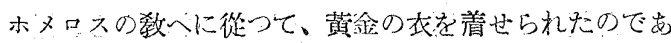
る。が、神かが果して黄金を愛したであららか。兴金を 愛した外のは人間でまる。:彼は黃金を愛するが故に神像 を作り、やがて神を珼つをのである。いはんや人間同志 
をや—かくてりクラテスとプラトンそは暮れゆくアテ ナイの街を眺めつ」悲憤慷啭する……

ックラテスは語つた「……吾㻎は知つてるる、あの プロタゴラスといふ男が、たつたー人で小賢しくる、

多額の黄白をせしめたことを。おんなにも尊い創作を したプェデイアスよりる、ク至は誰彼の十人もの彫像 家などよりも」と。(Platon: "Menon”, 91.).

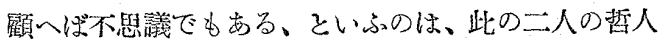
が、前にはアクロポりスに就いて、まな今プエディアス に就いて語つたが、それ等はいづれも金金锤問題に關聯し てぶあつたではないか。更に不思議なのは、吾及は彼等

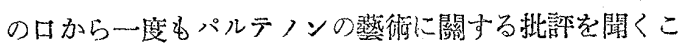
そが出來ないことだ。䈏し、斯かる事情の中にこそ、消

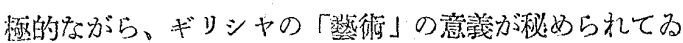
る。が、人及は尚漂、此の哲人の言葉の蕯から、不遇に

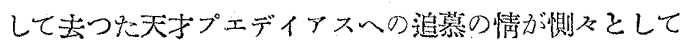
迫り來るの煘じないであららか。私はその文面から推 して、プラトンに於いてもまた。プエディアスの仕事は

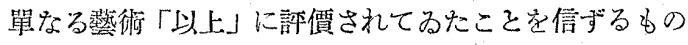
である。

$x \times x \quad x$

パルテノンが完成した時は、やがてアテナイが沒落し ゆく時であつた。神及は次及に責られて行つた。が、世
がギリシャである限り女神だけはとにかく無事であつ た。しかしやがて世が移るにつれて時には「デロスの勝 者がアクロポリスを"旅宿"としてパルテノスの堂の中 にその侍妾を宿泊させ、皮肉にもパルテノスを"わが 姉”と呼んだりした。298年にデメトリオスのために包 園されたラカレスは……筫金・象牙の像から異金の飾の 一部分を掠めて逃亡した」などいふ事もあつた。だがロ 一マ人もまた「アテナの威光に守護されたる此の㱆堂を 敬ふのに文でなかつ方」(Collignon, 富永譯 : op. cit.に よる)

その後の女神の滥命については誰し明らかに知るもの はない。幾分疑惊しい古文書によれば此の像はコンスタ ンチノポリスに連れゆかれたと考へられる。責金像牙の

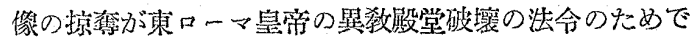
あつな事は疑ない。かくて、パルテノンが金塊眝蔵の金 庫であつた事を始めて端的に實證した者は一神々も御 照覽まれ——キリスト版徒だつたのである。

パルテノンの建物は、此時䒧にして特別の事情からそ の全壤を他れた。此のギリシヤの秆殿はキリスト教の會 堂として、その壁穵破られて改造される事となつた。パ ルテノンに探光の㣽めの塋が必要となつたのは、蓋し此 の時以後の事でしかないのである。

(Jan. 15. 1936) 